\title{
PURCHASE DECISIONS FROM SOCIAL MEDIA MARKETING, PRODUCT INNOVATION, AND CELEBRITY ENDORSER
}

\author{
Safira Ardian Sagita*1, Sarsono ${ }^{2}$ \\ Universitas Islam Batik, Indonesia*12 \\ safirafira054@gmail.com ${ }^{\star 1}$, sarsono1964@gmail.com²
}

\begin{abstract}
Investing or saving with gold is in great demand today, in an easy way and everyone can do it. Investment in the sale and purchase of old make the company very competitive. This study aims as a test of social media marketing, product innovation, celebrity endorser on purchasing decisions for jewelry at the Semar Nusantara gold shop Sukoharjo branch. The sample of this research is 100 consumers using the multiple linear regression method. Based on the results of research and discussion, social media marketing, product innovation, celebrity endorsers have a positive and significant effect on purchasing decisions at the Semar Nusantara gold shop. Social Media Marketing can influence purchasing decisions at the Semar Nusantara gold shop, Sukoharjo branch, which is one of the jewelry stores that keep up with the times, it can be said that because the jewelry shop offers online on social media, Instagram, and shopee in particular. So that millennials can buy online at the shopee @semarnusantara account and What's Up. With the social media Instagram @semarnusantara, customers can more easily find the latest information on the Semar Nusantara gold shop.
\end{abstract}

Keywords: Celebrity Endorser; Product Innovation; Purchase Decisions; Social Media Marketing

\section{INTRODUCTION}

From the past until now, buying gold can not only be used as jewelry to beautify themselves, especially women but can also be used as investment or savings. Nowadays, it is not only women who use jewelry in general, but now many men also use gold as jewelry. Now investing or saving with gold is very popular in all circles of society in addition to the high selling price, the purchase is also very easy for all people to understand. Purchase decision, the action of consumers to form references among brands in the choice group and buy the most preferred product (Willem et al., 2020). Today, companies must have their strategies to increase consumer buying interest. Most consumers will make purchases after seeing jewelry models on social media. Then look at the product innovation on offer. Some consumers make purchasing decisions after seeing celebrities promote and use the product. Many gold jewelry stores have started to take advantage of internet-based social media to market their business. Social media users can be used as a sales strategy, buying and selling transactions and product promotion processes simultaneously (Ryan, 2017). Instagram is an application that is often used for buying and selling promotions. Besides the many users, the Instagram application is also easy to operate. The increasingly diverse desires of consumers make companies know what consumers want. By way of finding out what is booming at the moment. Product innovation is needed nowadays, considering that there are many business competitors in the gold jewelry sector. Business actors must have product innovation and certain advantages compared to competitors so that they can attract consumers to just try and then make decisions to buy (Wiwid, 2017).

The online shop continues to compete by controlling its creative ideas so that its products can be recognized by all people. The use of ad stars in promotion is called celebrity endorse, through celebrity endorsers, marketers can differentiate from competitive products on the market (Kristanto et al., 2017). Celebrity endorsers are used to attracting public attention and can be expected to increase product awareness. 
Buying decision purchasing decisions are the behavior of consumers to choose between brands in the choice group and buy the most preferred product. of the various factors that influence consumers in buying a product or service, usually, consumers always consider quality, price, and products that are well known to the purchasing decision indicators according to (Sugianto, 2016), namely, type of product, seller, method of payment, necessity, will not move. social media marketing social media is a tool or way for consumers to share information in the form of text, images, audio, and videos with other people and companies or vice versa (Kotler \& Keller, 2016) Indicators: online communication, interaction, sharing content, accessibility, credibility (Ryan, 2017).

Product innovation is any item or product that has been developed or modified that is considered new. Product innovation is a company's effort to develop existing products so that consumers do not get bored with existing products on the market. Indicators: line expansion, new products, completely new products Celebrities by definition are people who are widely recognized by the public, be they movie stars, singers, athletes, or models who are known to the public for their achievements in different fields. Celebrities are the spokesperson for a brand (Spry et al., 2011). Someone who is well known to many people or works as an artist, influencer, public figure, model, etc. promotes a product by using and reviewing it on his account. Indicators: trustworthiness, expertise, disrespect, similarity.

The research objective is to know and explain the simultaneous influence of Social Media Marketing, Product Innovation, Celebrity Endorser on Purchasing Decisions at the Semar Nusantara Sukoharjo gold shop. Knowing and explaining the influence of Social Media Marketing on Purchasing Decisions at the Semar Nusantara Sukoharjo gold shop. Knowing and explaining the effect of Prosduk Innovation on Purchasing Decisions at the Semar Nusantara Sukoharjo gold shop. Knowing and partially explaining the influence of Celebrity Endorser on Purchasing Decisions at the Semar Nusantara Sukoharjo gold shop.

\section{METHODS}

This research was started by making observations or direct observations at the Semar Nusantara gold shop from October 2020 to January 2021. The population in this study were consumers at the Semar Nusantara gold shop Sukoharjo. Collecting data through a questionnaire with a Likert scale with criteria that strongly agree, agree, neutral, disagree, strongly disagree. With the analysis, a technique using multiple linear regression if the $p$-value $<0.05$, the independent variable affects the related variable.

\section{Respondent Description}

\section{RESULTS AND DISCUSSION}

Based on the questionnaire that has been distributed, the following data were obtained: female respondents (72\%), male respondents (28\%). Respondents who are still students (18\%), civil servants (27\%), private employees (29\%), entrepreneurs $(26 \%)$. Respondents who have purchased online (50\%), and who have never purchased online $(50 \%)$. 
Dependent Variable: KP

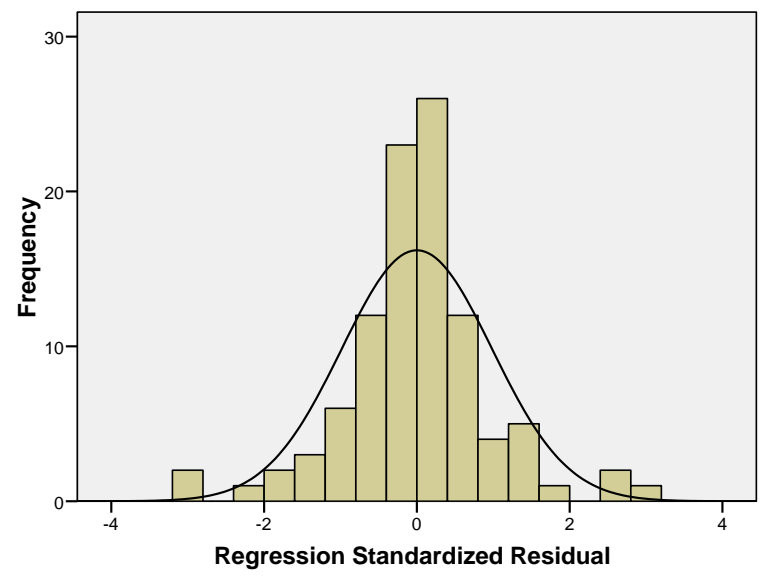

Figure 1. Histogram

Source: Processing SPSS (2020)
Mean $=4.18 \mathrm{E}-16$
Std. Dev. $=0.985$ $N=100$ curve.

The result of Figure 1 is a normal histogram graph because it forms a bell-like

Norm al P-P Plot of Regression Standardized Residual

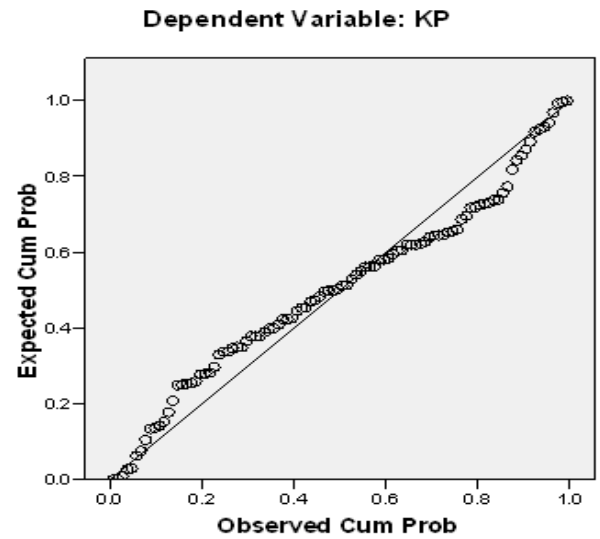

Figure 2. P-P Plot of Regression Standardized Residuals

Source: Processing SPSS (2020)

Results of Figure 2 P-P Plot of regression standardized residuals show that the data spread around the normal line and follows the line. It shows that the regression model is feasible to use.

Table 1. Multicollinearity Test B.

\begin{tabular}{lll}
\hline Variable & Tolerance & VIF \\
\hline Social Media Marketing & 0,596 & 1,677 \\
Product Innovation & 0,355 & 2,814 \\
Celebrity Endorser & 0,357 & 2,799 \\
\hline \multicolumn{2}{c}{ Source: Processing SPSS (2020) }
\end{tabular}


Results in Table 1, all tolerance values are above 0.1 and all VIF values are below 10. This shows that there is no multicollinearity between the independent variables.

Table 2. Heteroscedasticity Test

\begin{tabular}{ll}
\hline Variable & Significance \\
\hline Social Media Marketing & 0,045 \\
Product Innovation & 0,484 \\
Celebrity Endorser & 0,902 \\
\hline \multicolumn{2}{c}{ Source: Processing SPSS (2020) }
\end{tabular}

Results Table 2, variable $\mathrm{X} 1$ has a significant value below 0.05 . Meanwhile, $\mathrm{X} 2$ and $\mathrm{X} 3$ have a significant value above 0.05 . So it can be concluded that $\mathrm{X} 1$ Hiteroscedasticity occurs, while X2 and X3 do not occur Heteroscedasticity.

Table 3. Multiple Linear Regression Analysis

\begin{tabular}{ll}
\hline Variable & Regression Coefficient \\
\hline (Constant) & 5,533 \\
Social Media Marketing & 0,142 \\
Product Innovation & 0,053 \\
Celebrity Endorser & 0,010 \\
\hline
\end{tabular}

Source: Processing SPSS (2020)

A constant value of 5,533 , then the purchasing decision variable is 5,533 . Social Media Marking $(b 1)=0.142$. This shows if social media marketing increases by one unit, while the other variables are constant (zero). Then the purchase decision will increase by 0.142 . Product Innovation $(\mathrm{b} 2)=0.053$. This shows if the product innovation

increases one unit, while the other variables are constant (zero). Then the purchase decision will increase by 0.053 . Celebrity Endorser $(b 3)=0.010$. This shows if the celebrity endorser increases one unit, while the other variables are constant (zero). Then the purchase decision will increase by 0.010 .

\section{Table 4. Determination Test $\mathbf{P}$ (R2)}

$$
\frac{\overline{\text { Adjusted } \mathbf{R} \text { Square }}}{0,501}
$$

The value of $R$ Square is 0.501 . So the effect of the independent variable on the independent variable is $50.1 \%$. And the remaining $49.9 \%$ is influenced by other variables such as brand image, product quality, store atmosphere.

Table 5. F-Test

\begin{tabular}{lll}
\hline Variable & $\mathbf{F}_{\text {count }}$ & Sig. \\
\hline Social Media Marketing & 34,172 & 0,000 \\
$\begin{array}{l}\text { Product Innovation } \\
\text { Celebrity Endorser }\end{array}$ & 300 Source: Processing SPSS (2020)
\end{tabular}

The results of the analysis Fcount> Ftable (34.172> 2.70), then simultaneously the independent variables have influenced the decision to buy jewelry at the Semar Nusantara Sukoharjo shop. 


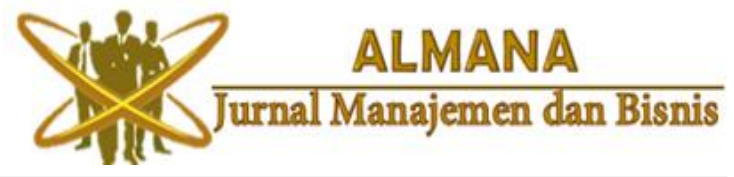

Table 6. T-Test

\begin{tabular}{lll}
\hline Variable & $\mathbf{T}_{\text {count }}$ & Sig. \\
\hline Social Media Marketing & 2,593 & 0,045 \\
Product Innovation & 2,205 & 0,030 \\
Celebrity Endorser & 2,998 & 0,003 \\
\hline \multicolumn{2}{c}{ Source: Processing SPSS (2020) }
\end{tabular}

The value of $t$ count $>t$ table (1.987) and all variables have a significant value less than 0.05 , so all variables have a partially positive effect on purchasing decisions at the Semar Nusantara gold shop. The influence of social media marketing on purchasing decisions. The results of this study indicate that social media marketing affects purchasing decisions at the Semar Nusatara gold shop. The regression coefficient value has a positive value. So with the social media marketing variable, it will increase. The effect of product innovation on purchasing decisions The results of this study indicate that product innovation affects purchasing decisions at the Semar Nusantara gold shop. The regression coefficient value has a positive value. So with the product innovation variable. The influence of celebrity endorsers on purchasing decisions. The results of this study indicate that celebrity endorsers affect purchasing decisions at the Semar Nusantara gold shop. The regression coefficient value has a positive value. So with the celebrity endorser variable, it will increase.

\section{CONCLUSION}

Based on the results of research and discussion, social media marketing, product innovation, celebrity endorsers have a positive and significant effect on purchasing decisions at the Semar Nusantara gold shop. Social Media Marketing can influence purchasing decisions at the Semar Nusantara gold shop, Sukoharjo branch, which is one of the jewelry stores that keep up with the times, it can be said that because the jewelry shop offers online on social media, Instagram, and shopee in particular. So that millennials can buy online at the shopee @semarnusantara account and What's Up. With the social media Instagram @semarnusantara, customers can more easily find the latest information on the Semar Nusantara gold shop.

\section{REFERENCES}

Kotler, P. \& Keller, L. K. (2016). Marketing Managemen, 15th Edition. Pearson Education, inc.

Kristanto, Okta Dwi, Ketut, Indraningrat \& Susanti Prasetiyaningtiyas. (2017). Pengaruh Viral Marketing, Celebrity Endorser, dan Brand Image Terhadap Keputusan Pembelian. Jurnal Bisnis dan Manajemen, 11(1). p. 62-75.

Ryan, Z. A. (2017). Pengaruh Social Media Marketing Terhadap Brand Trust Pada Followers Instagram Dompet Dhuafa Cabang Yogyakarta. Jurnal Manajemen Dakwah.

Spry, A., Pappu, R., \& Cornwell, B. (2011). Celebrity Endorsement, Brand Credibility, and Brand Equity. European Journal of Marketing.

Sugianto, P. C. (2016). . Pengaruh Media Sosial Terhadap Keputusan Pembelian Konsumen Cherie Melalui Minat Beli. Jurnal Manajemen Dan Start-up Bisnis.

Willem, Adrianus., Tumbel, Altje L., \& Samadi, Reitty L. (2020). Analisis Efektivitas Marketing Media Sosial Faacebook Terhadap Keputusan Pelanggan D'Brothers Laundry. JURNAL EMBA: JURNAL RISET EKONOMI, MANAJEMEN, BISNIS DAN AKUNTANSI, 8(1).

Wiwid, S. Y. (2017). Pengaruh Viral Maarketing, Celebrity Endorser Dan Brand image Terhadap Keputusan Pembelian Di Distro RMBL. Jurnal Bisnis Dan Manajemen. 